\title{
Article \\ Thermomagnesium: A By-Product of Ni Ore Mining as a Clean Fertilizer Source for Maize
}

\author{
João William Bossolani (ㄹ, Luiz Gustavo Moretti ${ }^{\mathbb{B}}$, José Roberto Portugal, Ricardo Rossi and \\ Carlos Alexandre Costa Crusciol * (D)
}

check for

updates

Citation: Bossolani, J.W.; Moretti, L.G.; Portugal, J.R.; Rossi, R.; Crusciol, C.A.C. Thermomagnesium: A By-Product of Ni Ore Mining as a Clean Fertilizer Source for Maize. Agronomy 2021, 11, 525. https:// doi.org/10.3390/agronomy11030525

Received: 11 February 2021

Accepted: 7 March 2021

Published: 11 March 2021

Publisher's Note: MDPI stays neutral with regard to jurisdictional claims in published maps and institutional affiliations.

Copyright: (c) 2021 by the authors. Licensee MDPI, Basel, Switzerland. This article is an open access article distributed under the terms and conditions of the Creative Commons Attribution (CC BY) license (https:// creativecommons.org/licenses/by/ $4.0 /)$.
Department of Crop Science, College of Agricultural Sciences, São Paulo State University (UNESP), Botucatu, SP 18610-034, Brazil; bossolani.agro@gmail.com (J.W.B.); souzamoretti@gmail.com (L.G.M.); jose.portugal@unesp.br (J.R.P.); ricardo.rossi@cmagfert.com.br (R.R.)

* Correspondence: carlos.crusciol@unesp.br

\begin{abstract}
This study explores whether Thermomagnesium (TM), a by-product of Ni ore mining, is an efficient fertilizer for maize. The effects of TM on soil $\mathrm{pH}$, the supply of $\mathrm{Si}$ and $\mathrm{Mg}$ to the soil and plants, carbohydrate metabolism, grain filling, and yield were assessed in two simultaneous experiments performed in greenhouse conditions. Five TM doses were applied to two soil texturesclayey $\left(0,55,273,709\right.$, and $\left.2018 \mathrm{mg} \mathrm{kg}^{-1}\right)$ and sandy $\left(0,293,410,645\right.$, and $\left.1260 \mathrm{mg} \mathrm{kg}^{-1}\right)$. In general, the best results in soil and maize plants occurred at the highest TM dose for both soil textures (clayey $2018 \mathrm{mg} \mathrm{kg}^{-1}$ and sandy $1260 \mathrm{mg} \mathrm{kg}^{-1}$ ). The results demonstrated that in both soils, the concentrations of $\mathrm{Mg}$ and $\mathrm{Si}$ in the maize leaves increased with the dose of $\mathrm{TM}$, similarly to that which occurred in the soil. Interestingly, in clayey soil, the soil pH increased linearly, whereas in sandy soil, the $\mathrm{pH}$ reached its maximum value between the two largest TM doses. The concentration of reducing sugars increased at the highest TM dose, whereas the concentrations of sucrose and starch decreased. The enhancement of carbohydrate partitioning led to higher maize growth, grain filling, and yield. Overall, the results clearly demonstrate that TM is a sustainable alternative fertilizer for maize and can be used for countless other crops and soil classifications, thus providing a suitable destination for this by-product of $\mathrm{Ni}$ ore mining.
\end{abstract}

Keywords: Zea mays (L); mining waste; magnesium silicate; carbohydrate partitioning; grain filling

\section{Introduction}

From an economic perspective, maize (Zea mays L.) is a global standout among crops because of its wide range of uses in human food, animal feed, and industrial applications [1]. This broad utility has also led to an increasing demand for maize [2]. Enhancing crop productivity is key for improving agricultural production and guaranteeing global food and energy supplies [3]. Fertilizers are the main inputs for increasing crop productivity quickly [4,5] and for replacing nutrients removed from the soil by crops [6]. Between 30 and $50 \%$ of crop productivity is attributable to fertilization, and thus fertilizer use is essential for food production in order to meet the demands of the growing world population [4].

Brazil is the fifth largest consumer of fertilizer in the world, and maize accounts for approximately $16 \%$ of its fertilizer use [7,8]. However, Brazil imports approximately $81 \%$ of its fertilizer $[9,10]$. A potential alternative source of nutrients is mining by-products [11,12], which would reduce the environmental problem of rock mining while providing a cleaner, domestic option for soil fertilization [13]. The use of by-products as a fertilizer in agriculture is an effective means of improving soil quality, increasing crop yields, and mitigating environmental impacts, while generating a new source of revenue [14].

One such by-product is Thermomagnesium (TM; or magnesium silicate $\left(\mathrm{MgSiO}_{3}\right)$ ), which originates from the extraction of nickel $(\mathrm{Ni})$ and has potential for use as a soil remineralizer to provide silicon $(\mathrm{Si})$ and magnesium $(\mathrm{Mg})$ to crops [12]. Si is a beneficial mineral element commonly found in the soil that increases plant resistance to stress by 
accumulating in the roots, stem, leaves, and bark [15]. In particular, supplying Si to plants can increase tolerance to water stress, thereby improving production stability, especially in regions subject to drought like the Brazilian Cerrado, a biome similar to the African savanna [16]. $\mathrm{Mg}$ is an important nutrient that is involved in several vital functions in plants $[17,18]$. Mg deficiency in plants may be caused not only by the depletion of soil reserves, but also by low $\mathrm{Mg}$ assimilation by roots as a result of competitive inhibition caused by the imbalance of cations such as calcium (Ca) and potassium (K) $[19,20]$. The reduced transport and accumulation of carbohydrates in $\mathrm{Mg}$-deficient leaves alter the photosynthetic carbon metabolism and restrict $\mathrm{CO}_{2}$ fixation $[17,21]$. $\mathrm{Mg}$ is closely linked to partitioning among starch synthesis, triose phosphate transport in the cytosol, and sucrose formation, and low $\mathrm{Mg}$ availability leads to a reduction of glucose-fructose bonds in cytosol [22].

To support the further development of TM as a fertilizer, the objective of the present study was to evaluate the effects of TM application on the supply of Si and $\mathrm{Mg}$ in sandy and clayey soil for the cultivation of maize, the partitioning of carbohydrates in the plants, grain yield, and the chemical attributes of the soil.

\section{Materials and Methods}

\subsection{Thermomagnesium Processing}

Thermomagnesium was produced by melting Ni ore in an electric furnace, which granulates nonmetallic elements, such as silicon dioxide $\left(\mathrm{SiO}_{2}\right)$, magnesium oxide $(\mathrm{MgO})$, and ferric oxide $\left(\mathrm{Fe}_{2} \mathrm{O}_{3}\right)$, in the presence of water. The ore was then crushed to alter its granulometry, followed by calcination in rotary kilns to remove all moisture, including chemically bound water. The calcined ore was subsequently charged in an electric furnace and was reduced at high temperature, which removed $\mathrm{O}$ from Fe and Ni oxides to produce an iron-nickel alloy (Fe-Ni) containing approximately $20 \% \mathrm{Ni}$, as well as a large amount of by-product [12].

The by-product was immediately cooled from $1600{ }^{\circ} \mathrm{C}$ to room temperature under pressure using several water jets. The solidified $\mathrm{MgSiO}_{3}$-rich by-product did not exhibit a granulometric uniformity and thus underwent a forming process. First, the by-product was dried in a rotary dryer at a beneficiation plant [12]. After drying, the particle size distribution (100 mesh size, $\sim 149 \mu \mathrm{m}$ ) was obtained by sieving, and the mineralogical phases of the by-product were determined by X-ray diffraction (XRD) in a Philips X-ray diffractometer (Table 1). The crystalline phases were identified by comparing the sample using the PDF2 Database of the International Center for Diffraction Data and the Inorganic Crystal Structure Database (ICSD; Figure 1). The values were calculated following the method of Rietveld [23], using the standard ICSD crystalline structures and internal fluorite $\left(\mathrm{CaF}_{2}\right)$ to determine the amorphous phase.

Table 1. Chemical composition of Thermomagnesium from nickel ore mining in São Paulo State, Brazil.

\begin{tabular}{|c|c|c|c|}
\hline Mineral Species & Chemical Formula & Abundance & Unit \\
\hline \multicolumn{4}{|c|}{ Chemical composition } \\
\hline Arsenic & $\mathrm{As}^{3+}$ & $<5$ & $\mathrm{mg} \cdot \mathrm{kg}^{-1}$ \\
\hline Cadmium & $\mathrm{Cd}^{2+}$ & $<5$ & $\mathrm{mg} \cdot \mathrm{kg}^{-1}$ \\
\hline Lead & $\mathrm{Pb}^{2+}$ & $<5$ & $\mathrm{mg} \cdot \mathrm{kg}^{-1}$ \\
\hline Mercury & $\mathrm{Hg}^{2+}$ & $<0.20$ & $\mathrm{mg} \cdot \mathrm{kg}^{-1}$ \\
\hline Selenium & $\mathrm{Se}^{2+}$ & $<0.10$ & $\mathrm{mg} \cdot \mathrm{kg}^{-1}$ \\
\hline Chromium & $\mathrm{Cr}^{3+}$ & 0.88 & $\%$ \\
\hline Nickel & $\mathrm{Ni}^{2+}$ & 0.11 & $\%$ \\
\hline \multicolumn{4}{|c|}{ Mineralogical phases } \\
\hline Amorphous phase & - & 74 & $\%$ \\
\hline Forsterite & $\mathrm{Mg}_{1.8} \mathrm{Fe}_{0.2} \mathrm{SiO}_{4}$ & 24 & $\%$ \\
\hline Lizardite & $\mathrm{Mg}_{3} \mathrm{Si}_{2}(\mathrm{OH})_{4} \mathrm{O}_{5}$ & 2 & $\%$ \\
\hline \multicolumn{4}{|c|}{ Mineral groups } \\
\hline Magnesium oxide & $\mathrm{MgO}$ & 28 & $\%$ \\
\hline Silicon dioxide & $\mathrm{SiO}_{2}$ & 48 & $\%$ \\
\hline
\end{tabular}



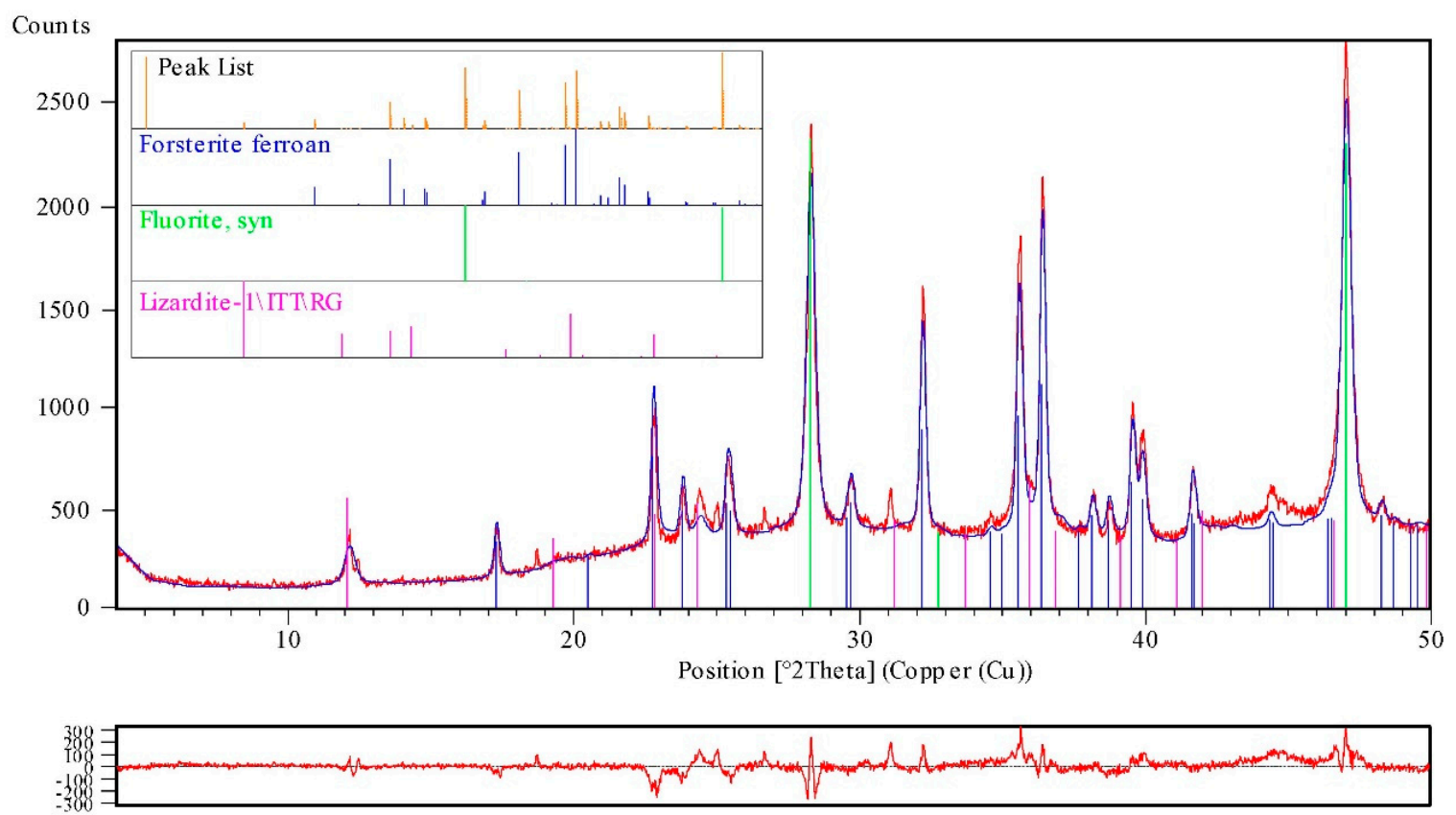

Figure 1. X-ray diffractogram for quantifying the mineralogical phases of Thermomagnesium from Ni ore mining. To calculate the amorphous material, $10 \%$ fluorite (ICDD 01-077-2093) was added.

According to the maximum limits of potentially toxic elements (PTEs; arsenic (As), cadmium $(\mathrm{Cd})$, chromium $(\mathrm{Cr})$, lead $(\mathrm{Pb})$, nickel $(\mathrm{Ni})$, mercury $(\mathrm{Hg})$ and selenium $(\mathrm{Se})$ ) in soil remineralizers allowed by the Brazilian National Environmental Council, as established by Annexe I of the Normative Instruction SDA n. 27 [24], TM does not represent an environmental risk (Table 1) and can be safely reused in agriculture.

\subsection{Experimental Conditions}

This study was conducted in an experimental greenhouse with a climate-controlled environment at the Lageado Experimental Farm of São Paulo State University (UNESP), which is located in the municipality of Botucatu in the southeastern region of São Paulo State, Brazil ( $48^{\circ} 26^{\prime} \mathrm{W}, 22^{\circ} 51^{\prime} \mathrm{S}$, elevation of $786 \mathrm{~m}$ above sea level). The greenhouse had an internal heating/cooling air circulatory system to maintain the temperature between $22{ }^{\circ} \mathrm{C}$ and $32{ }^{\circ} \mathrm{C}$, and had a $70 \%$ relative humidity. The experiment was performed using polyethylene pots with a capacity of $25 \mathrm{~kg}$ of soil.

According to the Brazilian Soil Classification System [25], the clayey soil used in the experiment was classified as a dystrophic Red Latosol, corresponding to a typical Ferralsol [26], and the sandy soil was a kaolinitic, thermic Typic Haplorthox [27]. The soil texture and bulk density [28], as well as the chemical properties [29], were determined at a $0.0-0.2 \mathrm{~m}$ depth (Table 2). For the soil acidity correction, base saturation (aiming to obtain $60 \%$ base saturation) was conducted by adding calcium carbonate $\left(\mathrm{CaCO}_{3} ;>99 \%\right.$, p.a., Sigma-Aldrich, Inc., St. Louis, MO, USA). Each pot was filled with air-dried soil mixed homogeneously with $\mathrm{CaCO}_{3}$ and the specified TM dose, and was incubated for $\sim 40$ days to allow for a reaction with the soil.

Prior to the experiment, the soil water retention capacity was determined using a tension table and a Richards extraction chamber [30] in order to calculate the soil water potential $\left(\psi_{\mathrm{w}}\right)$. 
Table 2. Physicochemical properties of soil types (0.00-0.20 m depth) in São Paulo, Brazil.

\begin{tabular}{|c|c|c|c|c|}
\hline \multirow{2}{*}{\multicolumn{2}{|c|}{ Soil Properties }} & \multirow{2}{*}{ Unit } & Clayey & Sandy \\
\hline & & & \multicolumn{2}{|c|}{ Value } \\
\hline \multicolumn{2}{|l|}{ Clay } & $\mathrm{g} \cdot \mathrm{kg}^{-1}$ & 602 & 251 \\
\hline \multicolumn{2}{|l|}{ Silt } & $\mathrm{g} \cdot \mathrm{kg}^{-1}$ & 281 & 25 \\
\hline \multicolumn{2}{|l|}{ Sand } & $\mathrm{g} \cdot \mathrm{kg}^{-1}$ & 117 & 724 \\
\hline \multicolumn{2}{|l|}{ Bulk density } & $\mathrm{g} \cdot \mathrm{cm}^{-3}$ & 1.19 & 1.26 \\
\hline \multicolumn{2}{|l|}{$\mathrm{pH}_{(\mathrm{CaCl} 2)}$} & - & 5.20 & 5.40 \\
\hline \multicolumn{2}{|c|}{ Soil organic matter } & $\mathrm{g} \cdot \mathrm{kg}^{-1}$ & 25.0 & 13.0 \\
\hline \multicolumn{2}{|c|}{ Available phosphorus ( $\left.\mathrm{P}_{\text {resin }}\right)$} & $\mathrm{mg} \cdot \mathrm{kg}^{-1}$ & 6.00 & 3.00 \\
\hline \multirow{4}{*}{ Exchangeable } & Calcium $\left(\mathrm{Ca}^{2+}{ }_{\text {resin }}\right)$ & $\mathrm{mmol}_{\mathrm{C}} \cdot \mathrm{kg}^{-1}$ & 35.0 & 18.0 \\
\hline & $\mathrm{Mg}\left(\mathrm{Mg}^{2+}\right.$ resin $)$ & $\mathrm{mmol}_{\mathrm{C}} \cdot \mathrm{kg}^{-1}$ & 8.00 & 2.00 \\
\hline & Potassium $\left(\mathrm{K}^{+}\right.$resin $)$ & $\mathrm{mmol}_{\mathrm{C}} \mathrm{kg}^{-1}$ & 0.70 & 0.50 \\
\hline & Aluminum $\left(\mathrm{Al}^{3+} \mathrm{KCl}\right)$ & $\mathrm{mmol}_{\mathrm{C}} \cdot \mathrm{kg}^{-1}$ & 0.00 & 0.00 \\
\hline \multicolumn{2}{|l|}{ Potential acidity $(\mathrm{H}+\mathrm{Al})$} & $\mathrm{mmol}_{\mathrm{C}} \cdot \mathrm{kg}^{-1}$ & 29.0 & 18.0 \\
\hline \multicolumn{2}{|c|}{ S-Sulfate $\left(\mathrm{S}-\mathrm{SO}_{4}{ }^{2-} \mathrm{Ca}(\mathrm{H} 2 \mathrm{PO} 4) 2\right)$} & $\mathrm{mg} \cdot \mathrm{kg}^{-1}$ & 9.00 & 6.00 \\
\hline \multicolumn{2}{|c|}{ Boron $\left(\mathrm{B}_{\text {Hot water }}\right)$} & $\mathrm{mg} \cdot \mathrm{kg}^{-1}$ & 0.40 & 0.30 \\
\hline \multicolumn{2}{|l|}{ Copper $\left(\mathrm{Cu}_{\text {DTPA-TEA }}{ }^{1}\right)$} & $\mathrm{mg} \cdot \mathrm{kg}^{-1}$ & 4.00 & 1.00 \\
\hline \multicolumn{2}{|c|}{ Iron (Fe DTPA-TEA) } & $\mathrm{mg} \cdot \mathrm{kg}^{-1}$ & 12.0 & 17.0 \\
\hline \multicolumn{2}{|c|}{ Manganese (Mn DTPA-TEA) } & $\mathrm{mg} \cdot \mathrm{kg}^{-1}$ & 13.2 & 2.20 \\
\hline \multicolumn{2}{|c|}{ Zinc ( $\mathrm{Zn}$ DTPA-TEA) } & $\mathrm{mg} \cdot \mathrm{kg}^{-1}$ & 0.90 & 0.40 \\
\hline \multicolumn{2}{|c|}{ Base saturation (BS) } & $\%$ & 60.0 & 53.3 \\
\hline \multicolumn{2}{|c|}{ Cation exchange capacity (CEC $\mathrm{pH} 7.0$ ) } & $\mathrm{mmol}_{\mathrm{C}} \cdot \mathrm{kg}^{-1}$ & 72.7 & 38.5 \\
\hline
\end{tabular}

${ }^{1}$ DTPA-TEA-diethylenetriaminepentaacetic acid-triethanolamine.

\subsection{Experimental Design and Treatments}

The experimental design was a completely randomized block with four replicates comprising four TM doses plus an absolute control for both soil textures. The treatments involved TM application to the soil at the following five doses: 0, 55, 273, 709, and $2018 \mathrm{mg}$ $\mathrm{kg}^{-1}$ for clayey soil, and $0,293,410,645$, and $1260 \mathrm{mg} \mathrm{kg}^{-1}$ for sandy soil. For both soils, doses were calculated respecting the Ca:Mg ratios (4:1, 3:1, 2:1, and 1:1). Maize seeds (hybrid P3707VYH; DuPont Pioneer ${ }^{\circledR}$, Johnston, IA, USA) for grain production purposes were treated with fungicides (carboxin and thiram at $100 \mathrm{~g}+100 \mathrm{~g}$ a.i. $100 \mathrm{~kg}^{-1}$ seeds) prior to planting. Nutrients were provided in the pots as needed for cultivation (Table 3) [31]. Five seeds were sown per pot, and the seedlings were thinned to three plants $10 \mathrm{~d}$ after sowing.

Table 3. Fertilization performed in the greenhouse experiment in Botucatu, São Paulo, Brazil.

\begin{tabular}{cccc}
\hline Nutrient & Dose & Unit & Source \\
\hline $\mathrm{N}$ & 50 & $\mathrm{mg} \cdot \mathrm{kg}^{-1}$ & $\mathrm{NH}_{4} \mathrm{NO}_{3}$ \\
$\mathrm{P}$ & $150^{1}$ & $\mathrm{mg} \cdot \mathrm{kg}^{-1}$ & $\mathrm{NH}_{4} \mathrm{NO}_{3}$ \\
$\mathrm{~K}$ & 200 & $\mathrm{mg} \cdot \mathrm{kg}^{-1}$ & $\mathrm{Ca}\left(\mathrm{H}_{2} \mathrm{PO}_{4}\right)_{2}$ \\
$\mathrm{Zn}$ & 50 & $\mathrm{mg} \cdot \mathrm{kg}^{-1}$ & $\mathrm{KCL}$ \\
$\mathrm{Mn}$ & $100^{1}$ & $\mathrm{mg} \cdot \mathrm{kg}^{-1}$ & $\mathrm{~K}_{2} \mathrm{SO}_{4}$ \\
$\mathrm{Fe}$ & 5.0 & $\mathrm{mg} \cdot \mathrm{kg}^{-1}$ & $\mathrm{ZnSO} 4.7 \mathrm{H}_{2} \mathrm{O}$ \\
$\mathrm{Cu}$ & 5.0 & $\mathrm{mg} \cdot \mathrm{kg}^{-1}$ & $\mathrm{MnSO} 4.3 \mathrm{H}_{2} \mathrm{O}$ \\
B & 2.5 & $\mathrm{mg} \cdot \mathrm{kg}^{-1}$ & $\mathrm{FeSO} 4.2 \mathrm{H}_{2} \mathrm{O}$ \\
\hline
\end{tabular}

${ }^{1}$ Topdressing at the $\mathrm{V}_{3}$ maize phenological stage.

The available water capacity was corrected to $-0.01 \mathrm{MPa}$ (field capacity), which corresponded to 110 and $129 \mathrm{~g} \mathrm{~kg}^{-1}$ for the clayey and sandy soils, respectively, corresponding to $60 \%-100 \%$ field capacity. Four reference pots were weighed every four days, and ster- 
ile distilled water was supplied as needed to restore the water content to field capacity $(-0.01 \mathrm{MPa})$.

\subsection{Soil-Plant Sampling and Analysis}

At the $\mathrm{R}_{1}$ phenological stage [32] (silking), 20 leaves were collected from 20 different plants of each plot and were milled in a Wiley-type mill coupled to a 1-mm sieve to determine the $\mathrm{Mg}$ and Si contents [33]. The same milled leaf samples were also subjected to sugar fractionation by high-performance liquid chromatography (HPLC) on a Shimadzu model 10A chromatograph with an RID-10A refractive index detector and model LC-10AD isocratic pump. Purified water was used as the mobile phase at a flow rate of $0.6 \mathrm{~mL}$ $\mathrm{min}^{-1}$. Prior to HPLC, $1.0 \mathrm{~g}$ of leaf sample and $8.0 \mathrm{~g}$ of purified water were weighed and incubated in a Marconi metabolic bath model MA095 at $60{ }^{\circ} \mathrm{C}$ for $40 \mathrm{~min}$ with constant agitation. After subsequent centrifugation at $12,000 \mathrm{rpm}$, the supernatant was filtered through a millipore polyvinylidene fluoride (PVDF) membrane with a porosity of $0.22 \mathrm{~m}$ and diameter of $13.0 \mathrm{~mm}$. The samples were then injected into the HPLC system, and the resulting chromatograms were compared with those of defined concentrations of sucrose, glucose, and fructose (reducing sugars). The concentrations of sucrose and reducing sugars were calculated by comparing their areas with those of the standards, and then multiplying by the dilution of each sample. The starch concentration in the leaves [34] was determined using a spectrophotometer at $535 \mathrm{~nm}$.

Simultaneous with the leaf analysis, two plants were collected for dry matter analysis. The remaining plants were grown until the end of the cycle, and the weight of 100 grains (W100G) was converted to values on a dry weight basis by correcting for $13 \%$ moisture. The moisture was determined with an automatic measuring device (Gehaka G650i, Brazil). The grain yield was expressed as grams per plant.

After harvest, a soil sample from each pot was collected, and the $\mathrm{pH}$ and $\mathrm{Mg}$ and $\mathrm{Si}$ availability were analyzed. The soil $\mathrm{pH}$ was determined in calcium chloride $\left(\mathrm{CaCl}_{2}\right)$ suspensions at $0.01 \mathrm{~mol} \mathrm{~L}^{-1}$ (at a soil:solution ratio of 1:2.5). $\mathrm{Mg}$ availability was determined using resin [35], and $\mathrm{Si}$ availability was determined by spectrophotometry after extraction with $0.01 \mathrm{~mol} \mathrm{~L}^{-1} \mathrm{CaCl}_{2}$ [36].

\subsection{Statistical Analysis}

All data were initially analyzed via the Shapiro-Wilk test [37] for normality and the Levene's test for homoscedasticity [38], both at $p<0.05$; the UNIVARIATE procedure of SAS version 9.4 was used for the analysis (SAS Institute, 2015). The data were also tested for sphericity using the Bartlett test [39] via the FACTOR procedure of SAS version 9.4 [40]. The results indicated that all data were distributed normally $(\mathrm{W} \geq 0.90)$ and exhibited no sphericity. The data were then subjected to analysis of variance and polynomial regression analysis to construct TM dose-response curves for the measured soybean and soil traits using significant regression equations with the highest coefficients of determination. A heatmap was built using the Pearson correlation coefficients $(p \leq 0.05)$ among variables, and only significant correlations were shown. Principal component analysis (PCA) was performed using the statistical software Canoco v. 4.5.

\section{Results}

As the TM dose increased, the Mg and Si concentrations in maize leaves also increased $(p \leq 0.05)$ in both clayey and sandy soils (Figure 2$)$. When maize was established in clayey soil at the highest TM dose, the leaf $\mathrm{Mg}$ concentration reached $3.44 \mathrm{~g} \mathrm{~kg}^{-1}$ (Figure 2A), and the leaf $\mathrm{Si}$ concentration reached $15.42 \mathrm{~g} \mathrm{~kg}^{-1}$ (Figure 2B). In sandy soil, at the highest TM dose, the leaf concentrations of $\mathrm{Mg}$ and $\mathrm{Si}$ reached 3.76 and $15.55 \mathrm{~g} \mathrm{~kg}^{-1}$ (Figure 2C,D), respectively. 

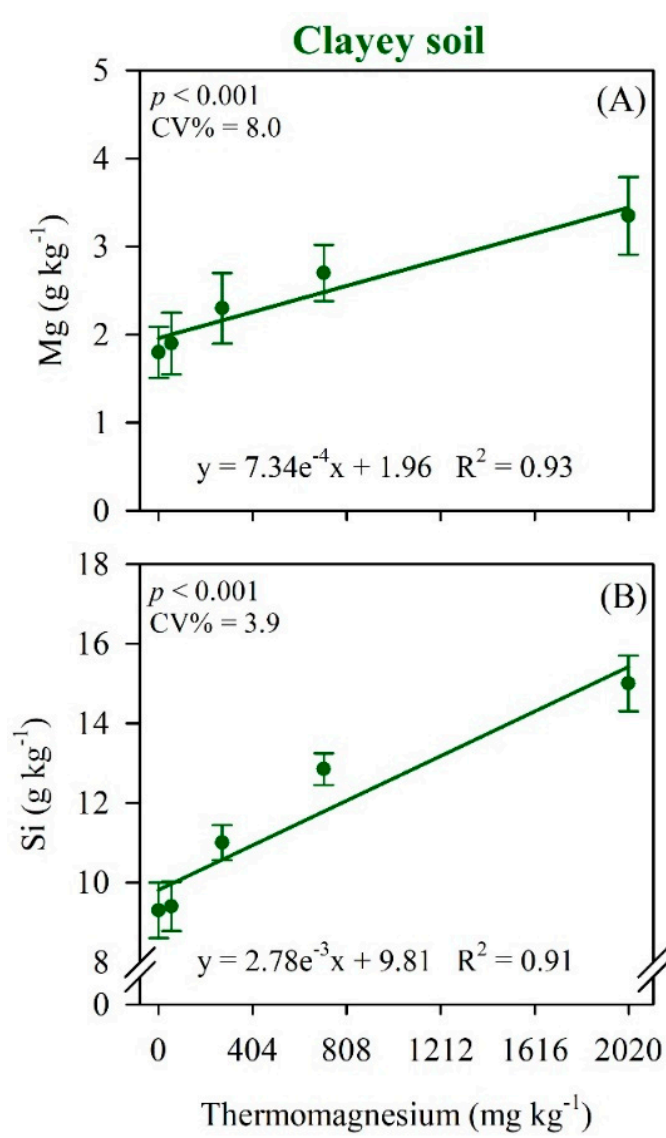
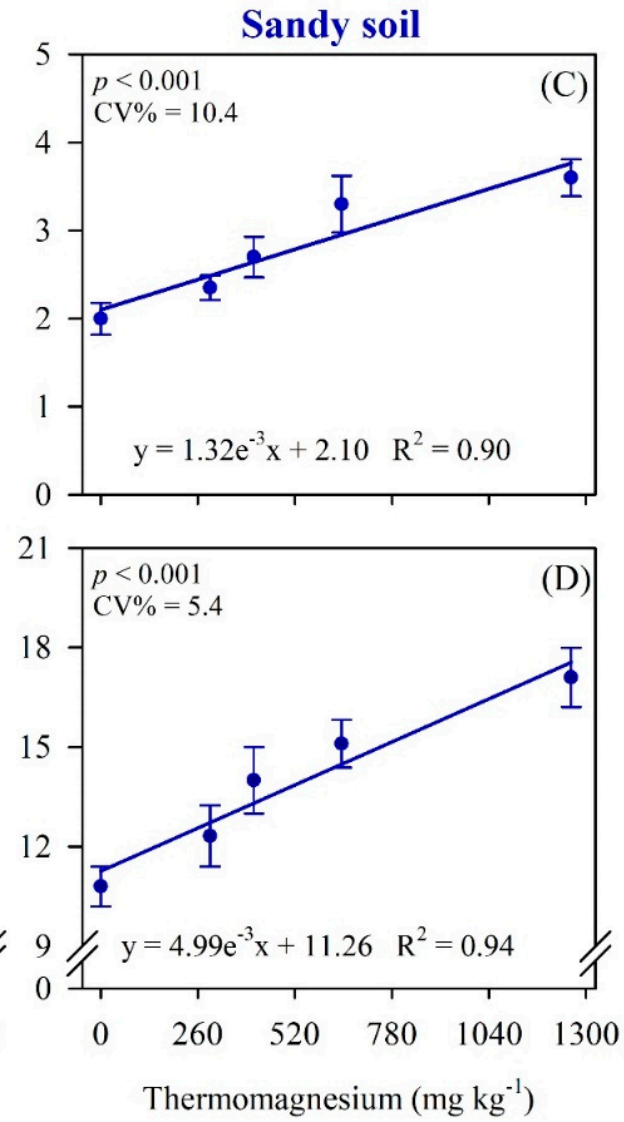

Figure 2. Leaf concentrations of $(\mathbf{A}, \mathbf{C}) \mathrm{Mg}$ and $(\mathbf{B}, \mathbf{D}) \mathrm{Si}$ in maize grown in clayey soil and sandy soil as a function of Thermomagnesium dose.

The concentrations of sugars in maize leaves also responded to the TM dose (Figure 3). The reducing sugars increased $(p \leq 0.05)$ linearly up to the highest TM dose, regardless of soil texture, reaching concentrations of $76.76 \mathrm{~g} \mathrm{~kg}^{-1}$ in clayey soil (Figure 3A) and $83.76 \mathrm{~g} \mathrm{~kg}^{-1}$ in sandy soil (Figure 3D). By contrast, the concentrations of sucrose and starch decreased $(p \leq 0.05)$ proportionally with the increasing TM dose, reaching their lowest values of $42.17 \mathrm{~g} \mathrm{~kg}^{-1}$ and $44.25 \mathrm{~g} \mathrm{~kg}^{-1}$, respectively, in clayey soil (Figure $3 \mathrm{~B}, \mathrm{C}$ ) and 54.07 and $53.21 \mathrm{~g} \mathrm{~kg}^{-1}$, respectively, in sandy soil (Figure 3E,F) at the highest TM dose.

The yield parameters and grain yield of the maize increased $(p \leq 0.05)$ with increasing the TM dose in both soils (Figure 4). The shoot dry matter reached $139 \mathrm{~g} \mathrm{plant}^{-1}$ in clayey soil (Figure 4A) and $138 \mathrm{~g} \mathrm{plant}^{-1}$ in sandy soil (Figure 4E). In both soils, the mean number of grains as a function of TM dose fit a quadratic equation $(p \leq 0.05)$. In clayey soil, the maximum grain yield per ear (418 grains) of maize occurred at a maximum technical efficiency dose (MTED) of $349 \mathrm{mg} \mathrm{kg}^{-1}$ (Figure 4B), whereas in sandy soil, the MTED was $490 \mathrm{mg} \mathrm{kg}^{-1}$ to produce a maximum of 421 grains per ear (Figure 4F). The maize W100G and grain yield increased $(p \leq 0.05)$ linearly with the TM dose in both soils. At the highest TM dose, the W100G was $28.04 \mathrm{~g}$ in clayey soil, and $28.93 \mathrm{~g}$ in sandy soil, while the grain yield was $115.4 \mathrm{~g} \mathrm{plant}^{-1}$ and $124 \mathrm{~g} \mathrm{plant}^{-1}$ (Figure $4 \mathrm{C}, \mathrm{G}, \mathrm{D}, \mathrm{H}$, respectively).

Increasing the TM dose also altered the chemical attributes $(p \leq 0.05)$ of both soils (Figure 5). The $\mathrm{pH}$ increased linearly with the TM dose in clayey soil, reaching $\mathrm{pH} 5.61$ at the highest dose (Figure 5A), whereas in sandy soil, the maximum pH was 5.75 at an MTED of $965 \mathrm{mg} \mathrm{kg}^{-1}$ (Figure 5D). Similar to the patterns of the leaf concentrations of $\mathrm{Mg}$ and $\mathrm{Si}$, the levels of these elements in soil increased linearly with the TM dose. At the highest TM dose, the available $\mathrm{Mg}^{2+}$ and Si levels reached $20.98 \mathrm{mmol}_{\mathrm{c}} \mathrm{kg}^{-1}$ and $14.5 \mathrm{mg} \mathrm{kg}^{-1}$, respectively, in clayey soil (Figure $5 \mathrm{~B}, \mathrm{C}$ ), and $8.95 \mathrm{mmol}_{\mathrm{C}} \mathrm{kg}^{-1}$ and $8.56 \mathrm{mg} \mathrm{kg}^{-1}$, respectively, in sandy soil (Figure 5E,F). 
Pearson's correlation analysis revealed different patterns of significant correlations $(p \leq 0.05)$ of the parameters between clayey and sandy soils (Figure 6). For maize established in clayey soil, significant correlations were observed among all parameters, except the number of grains per ear (Figure 6A). Only sucrose and starch were negatively correlated with the other parameters, but were positively correlated with each other. However, in sandy soil, soil available Si correlated significantly only with reducing sugar and available $\mathrm{Mg}^{2+}$ (Figure 6B), and $\mathrm{Mg}^{2+}$ did not correlate with shoot dry matter and W100G. Interestingly, in both soils, the grain yield was significantly correlated with W100G, but not the number of grains per ear.
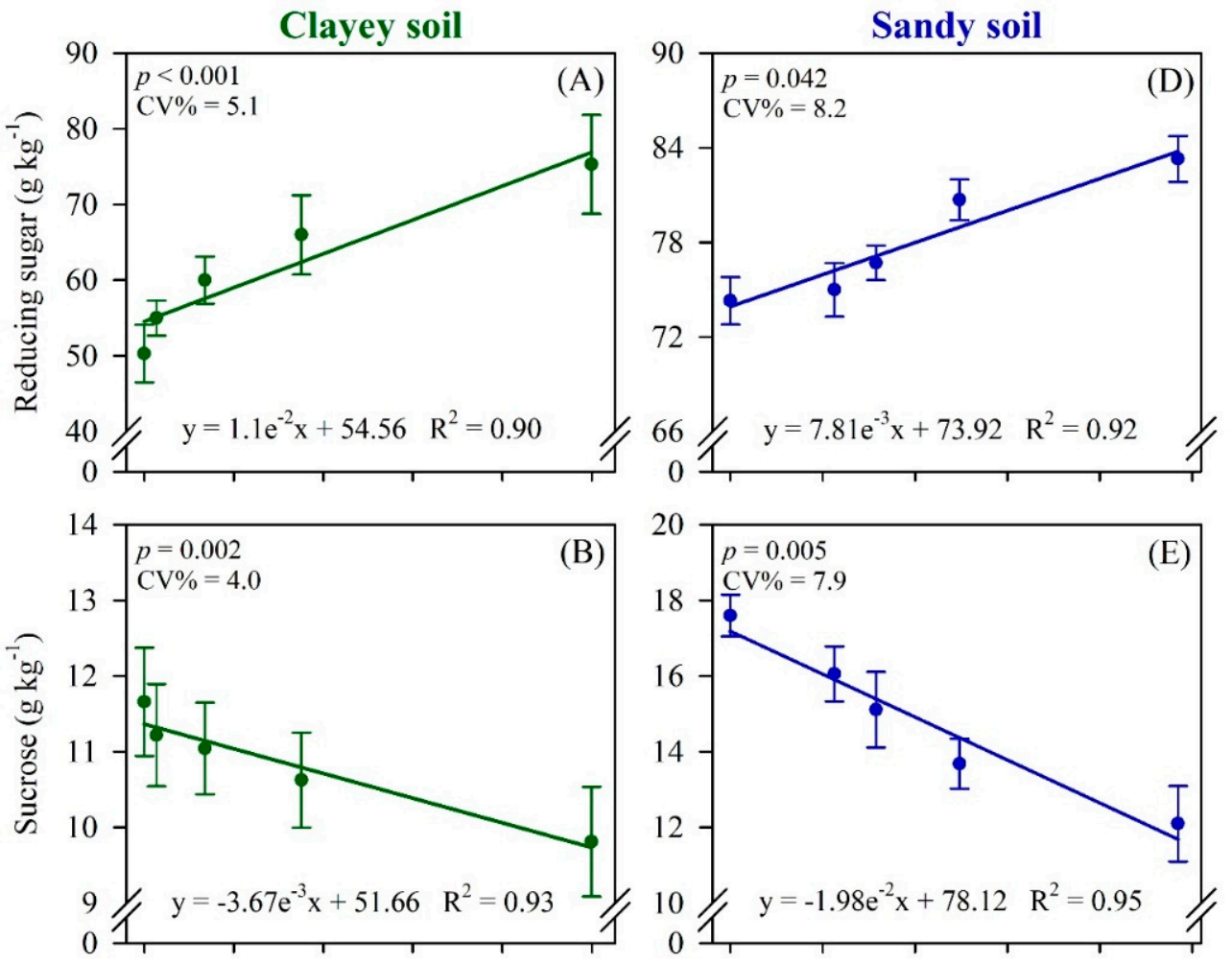

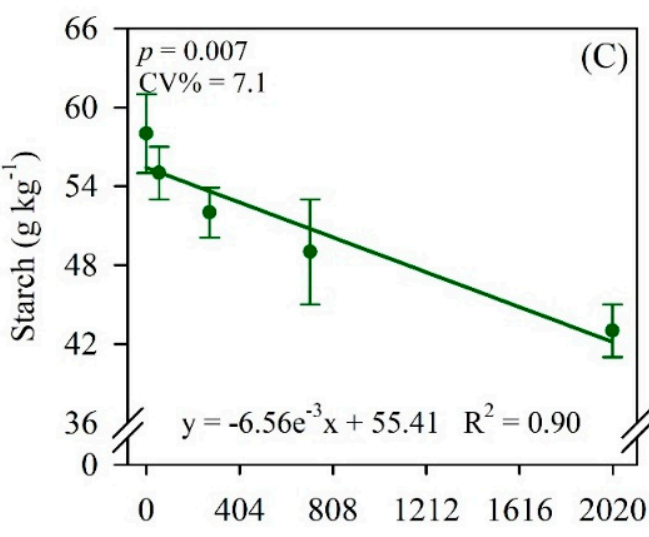

Thermomagnesium $\left(\mathrm{mg} \mathrm{kg}^{-1}\right)$

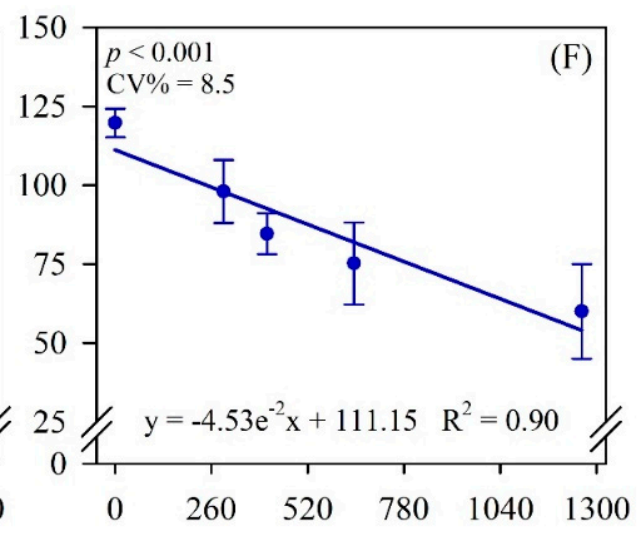

Thermomagnesium $\left(\mathrm{mg} \mathrm{kg}^{-1}\right)$

Figure 3. Leaf concentrations of (A,D) reducing sugars, $(\mathbf{B}, \mathbf{E})$ sucrose, and $(\mathbf{C}, \mathbf{F})$ starch in maize grown in clayey soil and sandy soil as a function of the Thermomagnesium dose. 

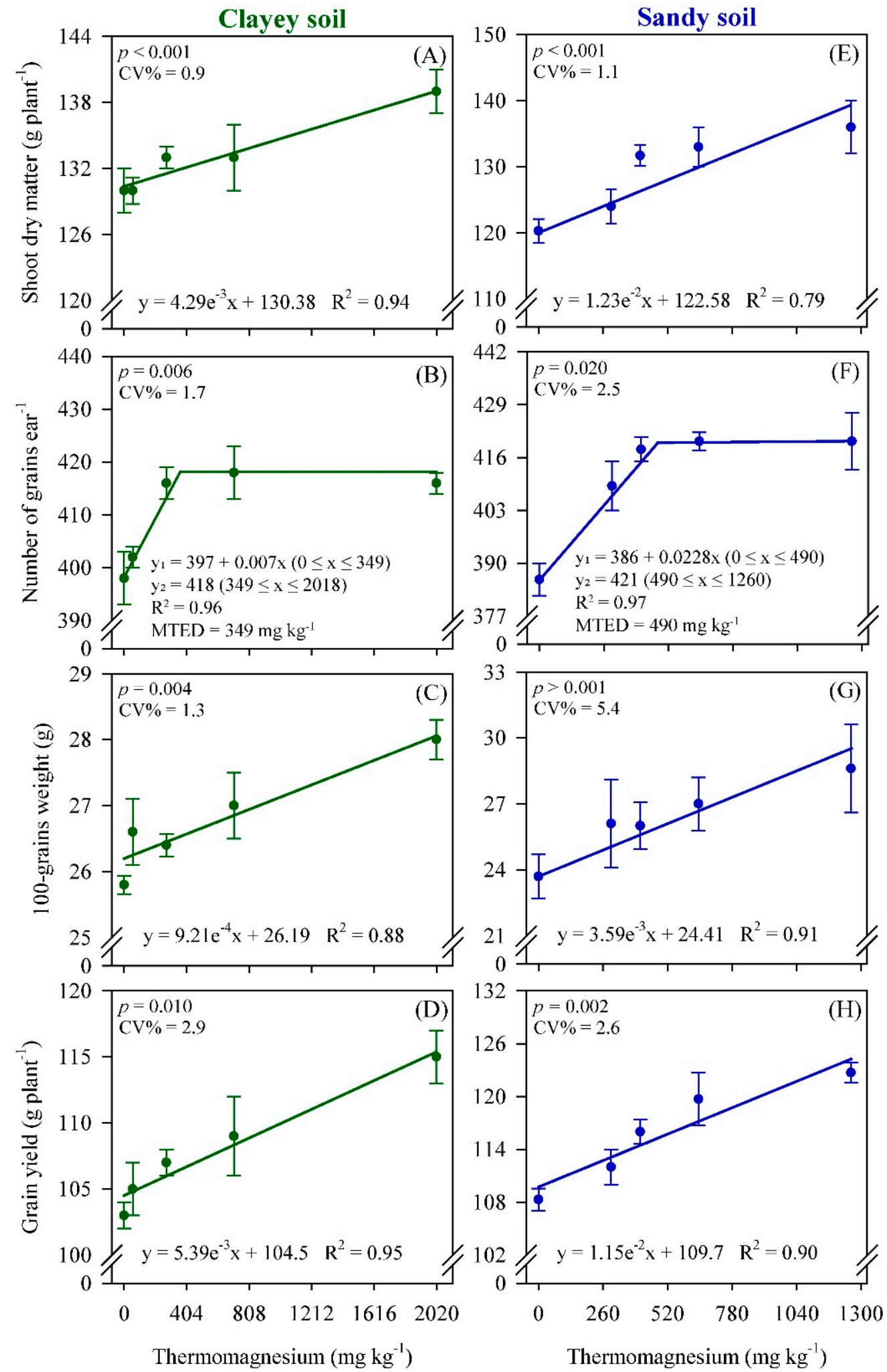

Figure 4. (A,E) Shoot dry matter, (B,F) number of grains per ear, $(\mathbf{C}, \mathbf{G})$ 100-grains weight, and $(\mathbf{D}, \mathbf{H})$ grain yield per plant of maize grown in clayey soil and sandy soil as a function of the Thermomagnesium dose. 
PCA clearly segregated the TM doses according to the general similarity of effects on all of the evaluated parameters. In clayey soil, both PCA and PERMANOVA indicated a greater similarity between the two lowest TM doses (control and $55 \mathrm{mg} \mathrm{kg}^{-1}$ ) and between the two subsequent doses (273 and $\left.709 \mathrm{mg} \mathrm{kg}^{-1}\right)$. The highest dose $\left(2018 \mathrm{mg} \mathrm{kg}^{-1}\right)$ showed unique behavior and was superior to the other doses, with the best responses of maize and soil parameters (Figure 6C). Similarly, in sandy soil, PCA showed a gradient of responses to TM dose (Figure 6D). PERMANOVA segregated the TM doses into three groups according to the general similarity of their effects on the following parameters: the control treatments of 293, 410, and $645 \mathrm{mg} \mathrm{kg}^{-1}$, and the highest TM dose, $1260 \mathrm{mg} \mathrm{kg}^{-1}$.
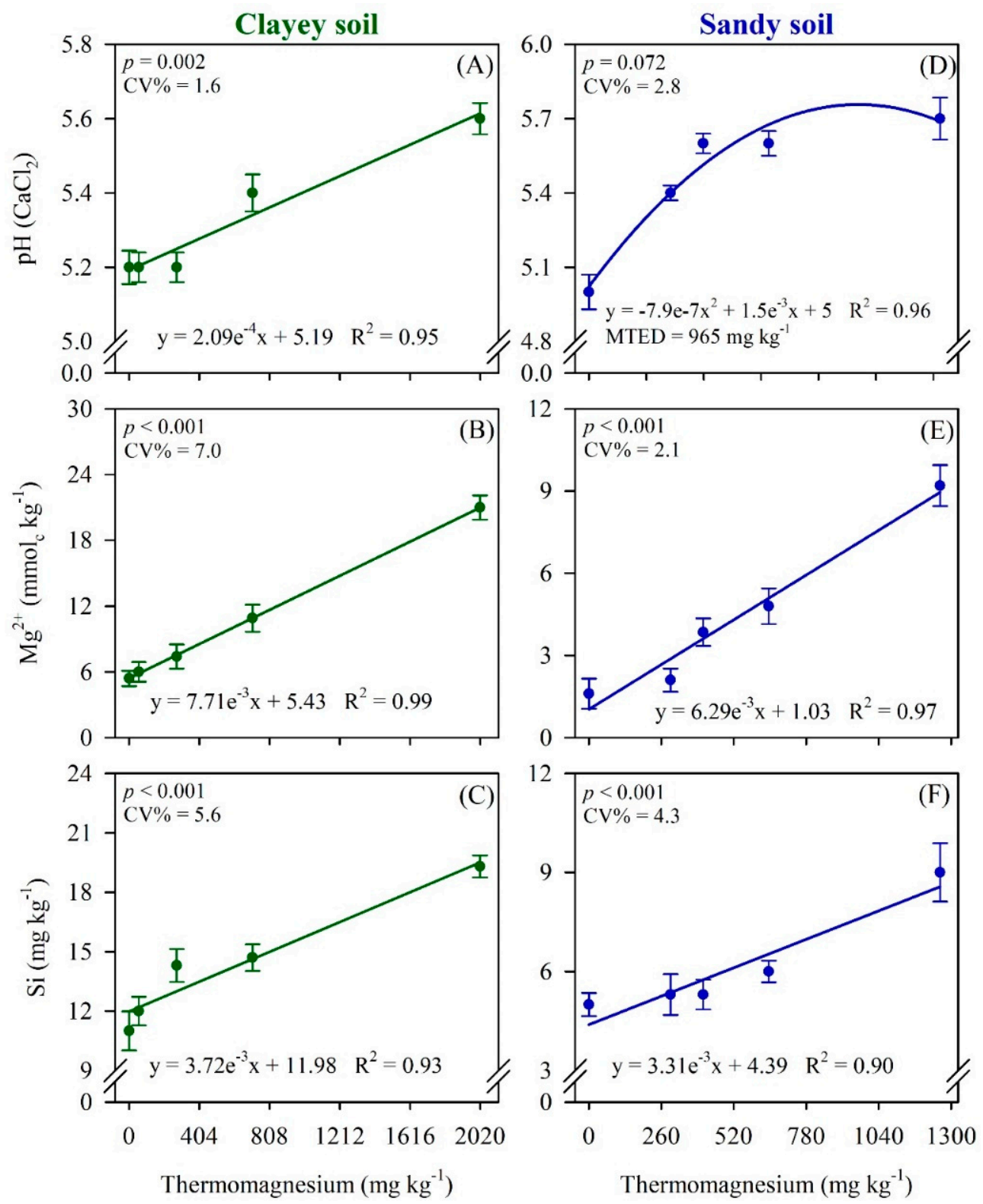

Figure 5. (A,D) Soil pH, (B,E) exchangeable $\mathrm{Mg}^{2+}$, and (C,F) Si availability in clayey and sandy soils as a function of the Thermomagnesium dose. 

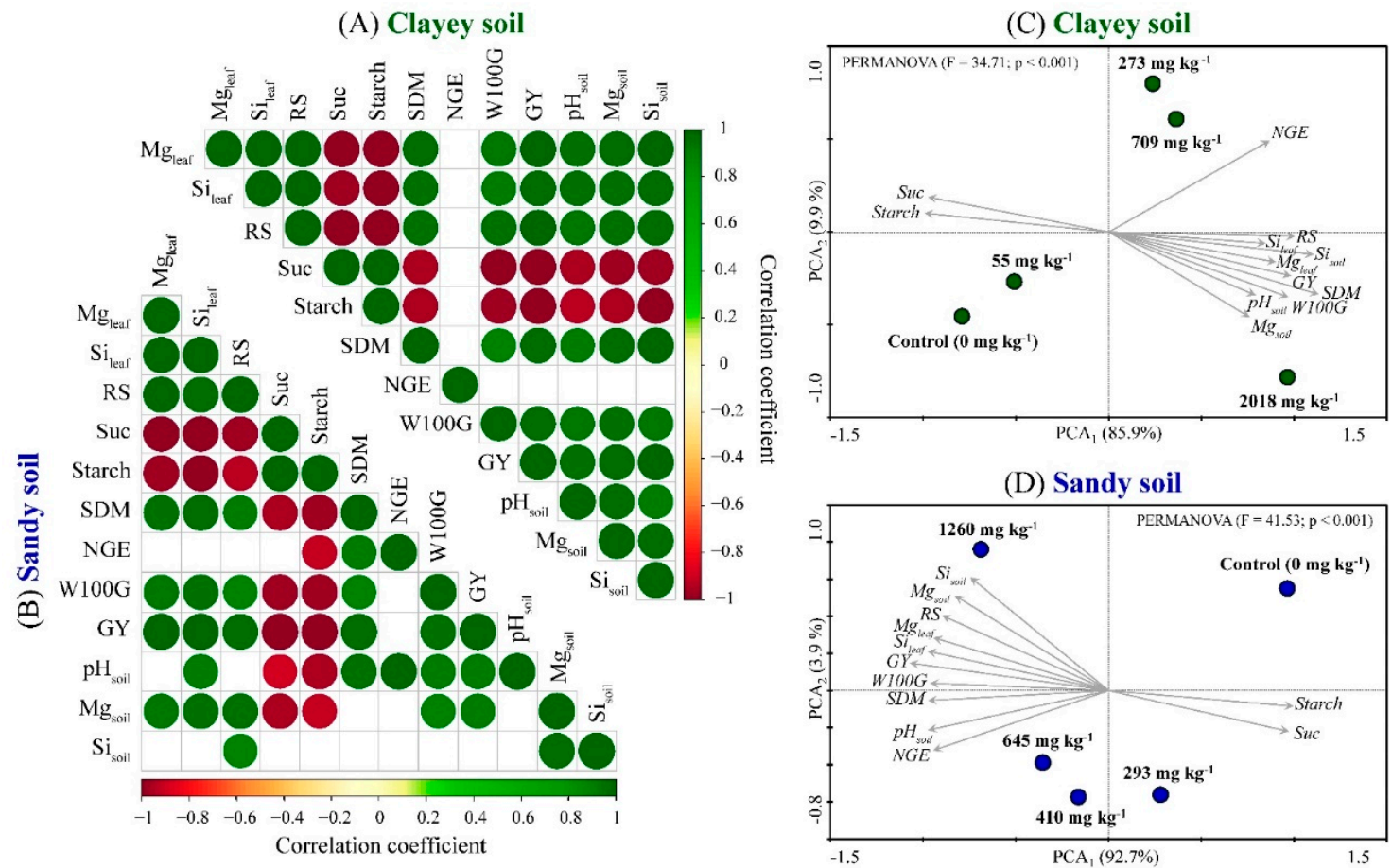

(D) Sandy soil

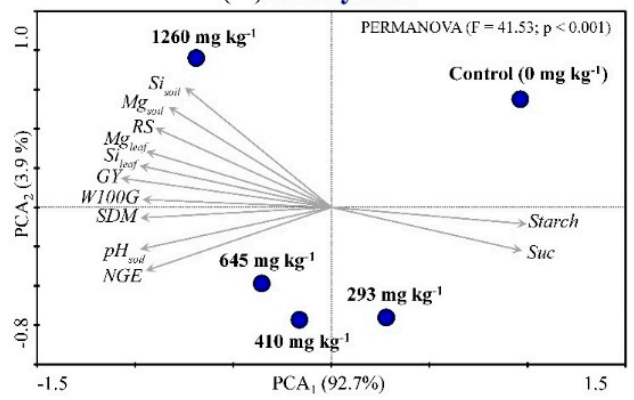

Figure 6. Heatmap of Pearson's correlation (A-Clayey soil, and B-Sandy soil) and principal component analysis (PCA) (C-Clayey soil, and D-Sandy soil) of soil and maize parameters. In the heatmap, only significant correlations at $p \leq 0.05$ are shown. Reducing sugar (RS), sucrose (Suc), shoot dry matter (SDM), number of grains per ear (NGE), weight of 100 grains (W100G), and grain yield (GY).

\section{Discussion}

The vast majority of studies of the reuse of industrial waste are limited to examining the petrography and mineralogy of these by-products and/or their potential use as nutrient remineralizers in soil $[13,41-43]$. By contrast, the present study investigated the direct impacts of supplying a by-product of $\mathrm{Ni}$ ore mining (TM) as a clean and sustainable fertilizer capable of improving plant metabolism and, consequently, maize grain yield.

Agricultural repurposing of TM as a Si-Mg fertilizer efficiently increased the levels of these elements in both the soil and maize leaves, particularly at the highest dose, as confirmed by PCA. Mg is considered a "forgotten" element in agriculture [44,45], and almost all Mg applied for agriculture comes from liming [46-48]. Thus, by-products such as TM provide a sustainable alternative for supplying $\mathrm{Mg}$ for cropping systems [12]. Supplying Mg to maize may improve crop growth and yield because of the important roles of $\mathrm{Mg}$ in plant metabolism, especially in photosynthesis and the activation of numerous key chloroplast enzymes [22,44,49,50].

Unfortunately, the impact of supplying $\mathrm{Si}$ to crops has received little attention [51]. $\mathrm{Si}$ is an important nutrient for plant growth and is the only nutrient that is not harmful when over-absorbed by plants [43]. Si relieves abiotic stress [52] by forming physical barriers through deposition in the cell wall of the plant, and may also activate plant defense enzymes to reduce the production of reactive oxygen species (ROS) [53], in addition to increasing crop productivity and quality $[54,55]$. The benefits of Si for crops are most evident in accumulating plants, such as maize, rice, wheat, barley, and pumpkin [53,56-58]. $\mathrm{Si}$ application is particularly beneficial for these crops, as the active uptake of $\mathrm{Si}$ occurs via transporters located on the plasma membrane [59,60]. TM could be an important alternative source of silicate for production systems, especially in acidic soils, which are typically Si-deficient [61].

Thermomagnesium also has a high neutralizing power for soil acidity [12], as it is composed of $51 \% \mathrm{SiO}_{3}{ }^{2-}$ and $28 \% \mathrm{MgO}$, which have respective neutralization capacities 
relative to $\mathrm{CaCO}_{3}$ of 1.0- and 2.48-fold, respectively [62]. Moreover, TM is more soluble than lime and thus may mitigate soil acidity more efficiently, in addition to providing $\mathrm{Mg}$ and Si to the soil [63], as observed in the soil and maize leaf analyses. Soil pH is an important determinant of $\mathrm{Mg}$ and $\mathrm{Si}$ availability in soil. As the TM level increased, soil $\mathrm{pH}$ increased linearly in clayey soil, but according to a quadratic model in sandy soil. The latter behavior can be explained by the low buffering power of sandy soil; as the $\mathrm{pH}$ increases, the effect of the acidity-correcting agent decreases [64]. Because of the low buffering power of sandy soils [65], caution is required in order to avoid excessive applications of soil amendments that drastically change the soil $\mathrm{pH}$, such as carbonate- and silicate-based amendments. Increasing the soil $\mathrm{pH}$ above the range considered suitable for most crops $\left(\mathrm{pH}\left(\mathrm{H}_{2} \mathrm{O}\right)\right.$ 5.5-6.5) reduces the availability of some nutrients, especially cationic micronutrients, for plant uptake as result of hydroxylation and subsequent precipitation [48,66-68]. As clayey soil naturally has a higher colloidal cation retention capacity, the $\mathrm{Mg}$ and Si concentrations were higher in the clayey soil than in the sandy soil.

The improvements in soil $\mathrm{pH}$ and $\mathrm{Si}-\mathrm{Mg}$ availability and in $\mathrm{Si}-\mathrm{Mg}$ plant nutrition also enhanced carbohydrate metabolism, mainly at higher doses, as supported by PCA. Like potassium $(\mathrm{K}), \mathrm{Mg}$ plays prominent roles in processes that are strongly associated with the photosynthesis and translocation of photosynthates [20,69]. Plant growth and metabolism are dependent on the translocation of carbohydrates from source-to-sink organs [20,45]. Sucrose is the main form of carbohydrate transported in plants, via phloem, and is greatly affected by Mg levels [22,44]. Mg scarcity reduces the efficiency of long-distance carbon transport [17], resulting in the accumulation of high levels of carbohydrates in leaves. The accumulation of carbohydrates leads to an increase in the production of reactive oxygen species (ROS) in chloroplasts, which limits photosynthetic efficiency through a negative feedback effect, further depriving sink organs of carbohydrates [17,44].

The dynamics among the concentrations of reducing sugars, sucrose and starch, in the leaves of the plant change depending on the availability of intracellular $\mathrm{Mg}$ [70]. In the presence of light, sucrose is transported from the leaf's cytosol to vascular tissues, and starch accumulates in the chloroplasts; at night, this starch serves as a carbon skeleton source for sucrose synthesis [71]. Reducing sugars are produced via carbon fixation, which can be increased by supplying $\mathrm{Mg}$ [70]. Our results suggest that along with the increase in the partitioning of photoassimilates, the photosynthetic activity and the production of reducing sugars increased. The enhanced partitioning of more complex sugars (sucrose and starch) to vascular organs reduces the concentrations of these sugars in the source leaves [17]. Our findings indicate that the translocation of sugars to vascular organs occurs efficiently, and that the plant's photosynthetic metabolism quickly replenishes these sugars to maintain high levels of reducing sugars in the cytosol. Similarly, the starch formed in the chloroplasts reduces the translocation of photosynthates because of their consumption as a source of carbon skeletons during respiration [22,71].

The observations of the vegetative and reproductive development of maize plants corroborated the results of the nutritional and carbohydrate analyses, with better results at the highest TM dose. This conclusion was also supported by PCA. Energy reserves are essential for cell multiplication by the plant. Thus, $\mathrm{Si}-\mathrm{Mg}$ supplementation of maize ensures greater efficiency of the photosynthetic metabolism. Magnesium acts directly in these processes, starting as a component of the chlorophyll molecule, through the activation of Rubisco in the process of carboxylation, and finally the partitioning of photoassimilates by the plant organs $[17,22,45]$. The plant converts this energy into dry matter accumulation during the vegetative stage and in grain filling in the reproductive stage. The number of grains per ear, W100G, and grain yield per plant were strongly affected by the TM application. A low response to the highest TM doses occurred for the number of grains per ear. The increase in these values may be related to the greater transport of photoassimilates to the ear during grain formation; however, the grain weight seemed to be the most determining factor of the grain yield. In both soil textures, the correlation analysis showed a strong correlation of grain yield with W100G, which is determined by the assimilation 
transport rate during the grain filling period $[72,73]$. The direct translocation of assimilates and the redistribution of the reserve pool of assimilates contribute to grain filling [22]. Starch is the most abundant component of cereal grains, and a reduced carbohydrate content or low translocation of this carbohydrate to the reproductive organs will reduce the grain weight [74]. Thus, reduced carbohydrate translocation to grains as a result of a low $\mathrm{Mg}$ supply will directly reduce the grain yield. In addition to the benefits of $\mathrm{TM}$ as a result of the supply of $\mathrm{Mg}$, the supply of Si by TM significantly enhances plant productive responses $[53,56]$. Si substantially improves the foliar architecture of plants, especially monocotyledons [59], favoring light interception, with a consequent increase in photosynthesis [56].

\section{Conclusions}

Our study confirmed that TM is yet another suitable and clean alternative fertilizer for agricultural systems that can improve soil $\mathrm{pH}$ and actively provide $\mathrm{Si}$ and $\mathrm{Mg}$ to soil and plants, regardless of soil texture, especially when applied at larger doses. Maize plants established in soils amended with TM were more metabolically active, redistributed their photosynthates appropriately among plant organs, and consequently reached a higher grain yield potential. Given these promising results, the application of TM as a new form of fertilizer should be considered for a variety of crops, soil conditions, and agricultural systems worldwide in order to help solve problems related to the disposal of by-products of mining, while simultaneously decreasing the consumption of highly soluble fertilizers.

Author Contributions: Conceptualization, J.W.B., R.R., and C.A.C.C.; methodology, L.G.M.; software, J.W.B.; validation, L.G.M. and J.R.P.; formal analysis, J.W.B.; investigation, J.R.P.; resources, R.R.; writing-original draft preparation, J.W.B.; writing—review and editing, L.G.M. and J.R.P.; supervision, C.A.C.C. All authors have read and agreed to the published version of the manuscript.

Funding: This research was funded by National Council for Scientific and Technological Development (CNPq), grant number: 303119/2016-0.

Institutional Review Board Statement: Not applicable.

Informed Consent Statement: Not applicable.

Data Availability Statement: The datasets analyzed during the current study are available from the corresponding author upon reasonable request.

Acknowledgments: The National Council for Scientific and Technological Development (CNPq) is acknowledged for the "Excellence in Research" award given to the fifth author. In addition, we would like to thank to Anglo American, Brazil, for their support.

Conflicts of Interest: The authors declare no conflict of interest.

\section{References}

1. Ranum, P.; Peña-Rosas, J.P.; Garcia-Casal, M.N. Global maize production, utilization, and consumption. Ann. N. Y. Acad. Sci. 2014, 1312, 105-112. [CrossRef]

2. FAO. The State of Food Security and Nutrition in the World 2019; FAO: Rome, Italy, 2019.

3. Sentelhas, P.C.; Battisti, R.; Câmara, G.M.S.; Farias, J.R.B.; Hampf, A.C.; Nendel, C. The soybean yield gap in Brazil-Magnitude, causes and possible solutions for sustainable production. J. Agric. Sci. 2015, 153, 1394-1411. [CrossRef]

4. Stewart, W.M.; Dibb, D.W.; Johnston, A.E.; Smyth, T.J. The contribution of commercial fertilizer nutrients to food production. Agron. J. 2005, 97, 1-6. [CrossRef]

5. Rehman, A.; Chandio, A.A.; Hussain, I.; Jingdong, L. Fertilizer consumption, water availability and credit distribution: Major factors affecting agricultural productivity in Pakistan. J. Saudi Soc. Agric. Sci. 2019, 18, 269-274. [CrossRef]

6. Goulding, K.; Jarvis, S.; Whitmore, A. Optimizing nutrient management for farm systems. Philos. Trans. R. Soc. B Biol. Sci. 2008, 363, 667-680. [CrossRef] [PubMed]

7. Heffer, P. Assessment of Fertilizer Use by Crop at the Global Level. Int. Fertil. Ind. Assoc. 2017, 5, 9.

8. Moretti, L.G.; Lazarini, E.; Bossolani, J.W.; Parente, T.L.; Caioni, S.; Araujo, R.S.; Hungria, M. Can additional inoculations increase soybean nodulation and grain yield? Agron. J. 2018, 110, 715-721. [CrossRef]

9. Moretti, L.G.; Bossolani, J.W.; Crusciol, C.A.C.; Moreira, A.; Micheri, P.H.; Rossi, R.; Imaizumi, C. Dunite in Agriculture: Physiological Changes, Nutritional Status and Soybean Yield. Commun. Soil Sci. Plant Anal. 2019, 50, 1775-1784. [CrossRef] 
10. Crusciol, C.A.C.; Moretti, L.G.; Bossolani, J.W.; Moreira, A.; Micheri, P.H.; Rossi, R. Can Dunite Promote Physiological Changes, Magnesium Nutrition and Increased Corn Grain Yield? Commun. Soil Sci. Plant Anal. 2019, 50, 2343-2353. [CrossRef]

11. Korchagin, J.; Caner, L.; Bortoluzzi, E.C. Variability of amethyst mining waste: A mineralogical and geochemical approach to evaluate the potential use in agriculture. J. Clean. Prod. 2019, 210, 749-758. [CrossRef]

12. Moretti, L.G.; Crusciol, C.A.C.; Bossolani, J.W.; Rossi, R.; Moreira, A. Agricultural repurposing of nickel slag residue. J. Plant Nutr. 2020. [CrossRef]

13. Dalmora, A.C.; Ramos, C.G.; Silva Oliveira, M.L.; Silva Oliveira, L.F.; Homrich Schneider, I.A.; Kautzmann, R.M. Application of andesite rock as a clean source of fertilizer for eucalyptus crop: Evidence of sustainability. J. Clean. Prod. 2020, $256,120432$. [CrossRef]

14. Das, S.; Galgo, S.J.; Alam, M.A.; Lee, J.G.; Hwang, H.Y.; Lee, C.H.; Kim, P.J. Recycling of ferrous slag in agriculture: Potentials and challenges. Crit. Rev. Environ. Sci. Technol. 2020, 2020, 1-35. [CrossRef]

15. Emamverdian, A.; Ding, Y.; Xie, Y.; Sangari, S. Silicon mechanisms to ameliorate heavy metal stress in plants. Biomed Res. Int. 2018, 2018, 8492898. [CrossRef]

16. Castro, G.S.A.; Crusciol, C.A.C. Effects of surface application of dolomitic limestone and calcium-magnesium silicate on soybean and maize in rotation with green manure in a tropical region. Bragantia 2015, 74, 311-321. [CrossRef]

17. Farhat, N.; Elkhouni, A.; Zorrig, W.; Smaoui, A.; Abdelly, C.; Rabhi, M. Effects of magnesium deficiency on photosynthesis and carbohydrate partitioning. Acta Physiol. Plant. 2016, 38. [CrossRef]

18. Garcia, A.; Crusciol, C.A.C.; McCray, J.M.; Nascimento, C.A.C.; Martello, J.M.; de Siqueira, G.F.; Tarumoto, M.B. Magnesium as apromoter of technological quality in sugarcane. J. Soil Sci. Plant Nutr. 2020, 20, 19-30. [CrossRef]

19. Castro, G.S.A.; Crusciol, C.A.C. Effects of superficial liming and silicate application on soil fertility and crop yield under rotation Geoderma 2013, 195-196, 234-242. [CrossRef]

20. Tränkner, M.; Tavakol, E.; Jákli, B. Functioning of potassium and magnesium in photosynthesis, photosynthate translocation and photoprotection. Physiol. Plant. 2018, 163, 414-431. [CrossRef]

21. Tränkner, M.; Jaghdani, S.J. Minimum magnesium concentrations for photosynthetic efficiency in wheat and sunflower seedlings. Plant Physiol. Biochem. 2019, 144, 234-243. [CrossRef] [PubMed]

22. Ceylan, Y.; Kutman, U.B.; Mengutay, M.; Cakmak, I. Magnesium applications to growth medium and foliage affect the starch distribution, increase the grain size and improve the seed germination in wheat. Plant Soil 2016, 406, 145-156. [CrossRef]

23. Young, R.A. The rietveld method. Int. Union Crystallogr. 1993, 5, 1-38.

24. Brazil Normative Instruction SDA/MAPA 27/2006. Available online: http://www.mma.gov.br/estruturas/ascom_boletins/ _arquivos /03042008_regulamentaprocedimentos.pdf (accessed on 20 June 2020).

25. Santos, H.G.; Jacomine, P.T.; Dos Anjos, L.H.C.; de Oliveira, V.A.; Lumbreras, J.F.; Coelho, M.R.; Almeida, J.A.; Araujo Filho, J.C.; Oliveira, J.B.; Cunha, T.J.F. Brazilian Soil Classification System-Portal Embrapa, 5th ed.; Embrapa Solos: Brasília, Brazil, 2018; ISBN 978-85-7035-817-2.

26. Jahn, R.; Blume, H.P.; Asio, V.B.; Spaargaren, O.; Schad, P. Guidelines for Soil Description; FAO: Rome, Italy, 2006.

27. Soil Survey Staff. Keys to Soil Taxonomy, 12th ed.; USDA-Natural Resources Conservation Service: Washington, DC, USA, 2014.

28. Donagema, G.K.; Viana, J.H.M.; Almeida, B.G.; Ruiz, H.A.; Klein, V.A.; Dechen, S.C.F.; Fernandes, R.B.A. Granulometric analysis. In Soil Analysis Methods Manual; Teixeira, P.C., Donagema, G.K., Fontana, A., Teixeira, W.G., Eds.; Embrapa Solos: Brasília, Brazil, 2017; pp. 95-116.

29. van Raij, B.; Quaggio, J.A.; Cantarella, H.; Abreu, C.A. Análise Química Para Avaliação da Fertilidade de Solos Tropicais; Instituto Agronômico: Campinas, Brazil, 2001.

30. Cassel, D.K.; Nielsen, D.R. Field Capacity and Available Water Capacity. In Methods of Soil Analysis: Part 1 Physical and Mineralogical Method; Klute, A., Ed.; American Society of Agronomy, Soil Sciense Society of America: Madison, WI, USA, 1986; Volume 2, pp. 901-926.

31. Moretti, L.G.; Crusciol, C.A.C.; Kuramae, E.E.; Bossolani, J.W.; Moreira, A.; Costa, N.R.; Alves, C.J.; Pascoaloto, I.M.; Rondina, A.B.L.; Hungria, M. Effects of growth-promoting bacteria on soybean root activity, plant development, and yield. Agron. J. 2020, 112, 418-428. [CrossRef]

32. Ritchie, S.W.; Hanway, J.J.; Benson, G.O. How a Corn Plant Develops; Special Report n. 48. Iowa State University of Science and Technology; Iowa State University: Ames, IA, USA, 1993.

33. Malavolta, E.; Vitti, G.C.; Oliveira, S.A. Evaluation of Nutritional Status of Plants: Principles and Applications, 2nd ed.; POTAFOS: Piracicaba, Brazil, 1997.

34. Nelson, N. A photometric adaptation of the Somogyi method for the determination of glucose. J. Biol. Chem. 1944, 153, 375-380. [CrossRef]

35. Embrapa. Manual de Métodos de Análise de Solo, 2nd ed.; EMBRAPA-CNPS: Rio de Janeiro, Brazil, 1997 ; Volume 26.

36. Korndörfer, G.H.; Pereira, H.S.; Nolla, A. Análise de silício: Solo, planta e fertilizante. In Uberlândia: GPSi-ICIAG-UFU (Boletim técnico, 2); Instituto de Ciências Agrárias, Universidade Federal de Uberlândia: Uberlândia, Brazil, 2004; p. 34.

37. Shapiro, S.S.; Wilk, M.B. An Analysis of Variance Test for Normality (Complete Samples). Biometrika 1965, 52, 591-611. [CrossRef]

38. Levene, H. Robust tests for equality of variances. In Contributions to Probability and Statistics: Essays in ... ; Olkin, I., Ghurye, S.G., Hoeffding, W., Madow, W.G., Mann, H.B., Eds.; Stanford University Press: Stanford, CA, USA, 1960; Volume 69, pp. $278-292$. 
39. Bartlett, M.S. Properties of sufficiency and statistical tests. Proc. R. Soc. London. Ser. A-Math. Phys. Sci. 1937, 160, 268-282. [CrossRef]

40. SAS Institute Procedure Guide for Personal Computers; Version 9.4; SAS Institute: Cary, NC, USA, 2015.

41. Plata, L.G.; Ramos, C.G.; Silva Oliveira, M.L.; Silva Oliveira, L.F. Release kinetics of multi-nutrients from volcanic rock mining by-products: Evidences for their use as a soil remineralizer. J. Clean. Prod. 2021, 279, 123668. [CrossRef]

42. Aquino, J.M.; Taniguchi, C.A.K.; Magini, C.; Berni, G.V. The potential of alkaline rocks from the Fortaleza volcanic province (Brazil) as natural fertilizers. J. S. Am. Earth Sci. 2020, 103, 102800. [CrossRef]

43. Dalmora, A.C.; Ramos, C.G.; Plata, L.G.; da Costa, M.L.; Kautzmann, R.M.; Oliveira, L.F.S. Understanding the mobility of potential nutrients in rock mining by-products: An opportunity for more sustainable agriculture and mining. Sci. Total Environ. 2020, 710, 136240. [CrossRef] [PubMed]

44. Cakmak, I.; Kirkby, E.A. Role of magnesium in carbon partitioning and alleviating photooxidative damage. Physiol. Plant. 2008, 133, 692-704. [CrossRef] [PubMed]

45. Hauer-Jákli, M.; Tränkner, M. Critical leaf magnesium thresholds and the impact of magnesium on plant growth and photooxidative defense: A systematic review and meta-analysis from 70 years of research. Front. Plant Sci. 2019, 10, 1-15. [CrossRef]

46. Li, Y.; Cui, S.; Chang, S.X.; Zhang, Q. Liming effects on soil $\mathrm{pH}$ and crop yield depend on lime material type, application method and rate, and crop species: A global meta-analysis. J. Soils Sediments 2019, 19, 1393-1406. [CrossRef]

47. Bossolani, J.W.; Lazarini, E.; Santos, F.L.; Sanches, I.R.; Meneghette, H.H.A.; Parra, L.F.; Souza, L.G.M. Surface Reapplication of Lime and Gypsum on Maize Cultivated Sole and Intercropped with Urochloa. Commun. Soil Sci. Plant Anal. 2018, 49, 1855-1868. [CrossRef]

48. Bossolani, J.W.; dos Santos, F.L.; Meneghette, H.H.A.; Sanches, I.R.; Moretti, L.G.; Parra, L.F.; Lazarini, E. Soybean in Crop Rotation with Maize and Palisade Grass Intercropping Enhances the Long-term Effects of Surface Liming in No-till System. J. Soil Sci. Plant Nutr. 2020, 21, 119-130. [CrossRef]

49. Jaghdani, S.J.; Jahns, P.; Tränkner, M. Mg deficiency induces photo-oxidative stress primarily by limiting $\mathrm{CO}_{2}$ assimilation and not by limiting photosynthetic light utilization. Plant Sci. 2021, 302, 110751. [CrossRef]

50. Siddiqui, M.H.; Alamri, S.A.; Al-Khaishany, M.Y.Y.; Al-Qutami, M.A.; Ali, H.M.; Al-Whaibi, M.H.; Al-Wahibi, M.S.; Alharby, H.F. Mitigation of adverse effects of heat stress on Vicia faba by exogenous application of magnesium. Saudi J. Biol. Sci. 2018, 25, 1393-1401. [CrossRef] [PubMed]

51. Preston, H.A.F.; Henrique de Sousa Nunes, G.; Preston, W.; Barbosa de Souza, E.; de Lima Ramos Mariano, R.; Datnoff, L.E.; Araújo do Nascimento, C.W. Slag-based silicon fertilizer improves the resistance to bacterial fruit blotch and fruit quality of melon grown under field conditions. Crop Prot. 2020, 105460, in press. [CrossRef]

52. Laxmanarayanan, M.; Prakash, N.B.; Dhumgond, P.; Ashrit, S. Slag-Based Gypsum as a Source of Sulphur, Calcium and Silicon and Its Effect on Soil Fertility and Yield and Quality of Groundnut in Southern India. J. Soil Sci. Plant Nutr. 2020, 20, $2698-2713$.

53. Luyckx, M.; Hausman, J.-F.; Lutts, S.; Guerriero, G. Silicon and plants: Current knowledge and technological perspectives. Front. Plant Sci. 2017, 8, 411. [CrossRef]

54. Keeping, M.G. Uptake of silicon by sugarcane from applied sources may not reflect plant-available soil silicon and total silicon content of sources. Front. Plant Sci. 2017, 8, 1-14. [CrossRef]

55. Beerling, D.J.; Leake, J.R.; Long, S.P.; Scholes, J.D.; Ton, J.; Nelson, P.N.; Bird, M.; Kantzas, E.; Taylor, L.L.; Sarkar, B.; et al. Farming with crops and rocks to address global climate, food and soil security. Nat. Plants 2018, 4, 138-147. [CrossRef]

56. Haynes, R.J. Significance and Role of Si in Crop Production. In Advances in Agronomy; Academic Press Inc.: Cambridge, MA, USA, 2017; Volume 146, pp. 83-166.

57. Yamaji, N.; Chiba, Y.; Mitani-Ueno, N.; Ma, J.F. Functional characterization of a silicon transporter gene implicated in silicon distribution in barley. Plant Physiol. 2012, 160, 1491-1497. [CrossRef]

58. Ma, J.F.; Yamaji, N.; Mitani, N.; Tamai, K.; Konishi, S.; Fujiwara, T.; Katsuhara, M.; Yano, M. An efflux transporter of silicon in rice. Nature 2007, 448, 209-212. [CrossRef] [PubMed]

59. Guntzer, F.; Keller, C.; Meunier, J.-D. Benefits of plant silicon for crops: A review. Agron. Sustain. Dev. 2012, 32, 201-213. [CrossRef]

60. Deshmukh, R.; Bélanger, R.R. Molecular evolution of aquaporins and silicon influx in plants. Funct. Ecol. 2016, 30, 1277-1285. [CrossRef]

61. Tavakkoli, E.; Lyons, G.; English, P.; Guppy, C.N. Silicon nutrition of rice is affected by soil pH, weathering and silicon fertilisation. J. Plant Nutr. Soil Sci. 2011, 174, 437-446. [CrossRef]

62. Alcarde, J.C. Corretivos da Acidez dos Solos: Características e Interpretações Técnicas; Associação Nacional para Difusão de Adubos ANDA: São Paulo, Brazil, 1992.

63. Crusciol, C.A.C.; Artigiani, A.C.C.A.; Arf, O.; Carmeis Filho, A.C.A.; Soratto, R.P.; Nascente, A.S.; Alvarez, R.C.F. Soil fertility, plant nutrition, and grain yield of upland rice affected by surface application of lime, silicate, and phosphogypsum in a tropical no-till system. Catena 2016, 137, 87-99. [CrossRef]

64. Crusciol, C.A.C.; Rossato, O.B.; Foltran, R.; Martello, J.M.; Nascimento, C.A.C. do Soil fertility, sugarcane yield affected by limestone, silicate, and gypsum application. Commun. Soil Sci. Plant Anal. 2017, 48, 2314-2323. [CrossRef]

65. Kolahchi, Z.; Jalali, M. Effect of water quality on the leaching of potassium from sandy soil. J. Arid Environ. 2007, 68, 624-639. [CrossRef] 
66. Bossolani, J.W.; Crusciol, C.A.C.; Merloti, L.F.; Moretti, L.G.; Costa, N.R.; Tsai, S.M.; Kuramae, E.E. Long-term lime and gypsum amendment increase nitrogen fixation and decrease nitrification and denitrification gene abundances in the rhizosphere and soil in a tropical no-till intercropping system. Geoderma 2020, 375, 114476. [CrossRef]

67. Barber, S.A. Soil Nutrient Bioavailability: A Mechanistic Approach; John Wiley \& Sons: Hoboken, NJ, USA, 1995.

68. Lindsay, W.L. Inorganic equilibria affecting micronutrients in soils. Micronutr. Agric. 1991, 4, 89-112.

69. Cakmak, I.; Hengeler, C.; Marschner, H. Partitioning of shoot and root dry matter and carbohydrates in bean plants suffering from phosphorus, potassium and magnesium deficiency. J. Exp. Bot. 1994, 45, 1245-1250. [CrossRef]

70. Garten, C.T. Correlations between concentrations of elements in plants. Nature 1976, 261, 686-688. [CrossRef]

71. Jonik, C.; Sonnewald, U.; Hajirezaei, M.; Flügge, U.; Ludewig, F. Simultaneous boosting of source and sink capacities doubles tuber starch yield of potato plants. Plant Biotechnol. J. 2012, 10, 1088-1098. [CrossRef]

72. Prathap, V.; Ali, K.; Singh, A.; Vishwakarma, C.; Krishnan, V.; Chinnusamy, V.; Tyagi, A. Starch accumulation in rice grains subjected to drought during grain filling stage. Plant Physiol. Biochem. 2019, 142, 440-451.

73. Li, Q.; Du, L.; Feng, D.; Ren, Y.; Li, Z.; Kong, F.; Yuan, J. Grain-filling characteristics and yield differences of maize cultivars with contrasting nitrogen efficiencies. Crop J. 2020, 8, 990-1001. [CrossRef]

74. Wang, X.; Cai, J.; Liu, F.; Jin, M.; Yu, H.; Jiang, D.; Wollenweber, B.; Dai, T.; Cao, W. Pre-anthesis high temperature acclimation alleviates the negative effects of post-anthesis heat stress on stem stored carbohydrates remobilization and grain starch accumulation in wheat. J. Cereal Sci. 2012, 55, 331-336. [CrossRef] 